\title{
European Union and German law on co- existence: Individualisation of a systemic problem
}

\author{
Gerd Winter ${ }^{*}$ and Sarah Stoppe-Ramadan ${ }^{*}$
}

\begin{abstract}
Background: Co-existence of the cultivation of genetically modified and non-genetically modified crops is commonly regarded as a suitable way out of the clash of perceptions of environmental or health risks of genetically modified organisms. It allows setting aside a clear risk-based decision for or against genetically modified organisms, because all types of agriculture shall be given the possibility to exist side by side.

Still, co-existence entails conflicts which the law strives to solve. European Union law is reticent as to binding coexistence measures and has left this task to the member states. Taking Germany as a case, the established rules have not been effective because they shift conflict resolution to the local and individual level. A systemic approach suggests the use of landscape planning as a means of clustering different kinds of agriculture.
\end{abstract}

Methods: The pertinent European Union and German law is summarised and interpreted. Its effects are analysed and explained. From this reform, suggestions are derived.

Results: According to the European Union, conception measures aiming at reducing health and environmental risks of genetically modified organisms must be separated from measures aiming at ensuring the economic coexistence of different kinds of agriculture. In contrast, German law on gene technology does not precisely separate risk mitigation measures from co-existence measures. The measures all aim at solving the conflicts between the individual landowners and thus fail to recognise the systemic character of the conflict between agricultures. The systemic conflict can better be solved by non-binding landscape planning or a legally binding agrarian utilisation plan, yet to be developed. Legislation addressing the conflict of agriculture must respect its constitutional dimension, i.e. the clash of basic rights to property and entrepreneurial freedom of conventional, organic and genetically modified organism farmers, industry, commerce and consumers. Binding and non-binding planning measures are compatible with constitutional guarantees as well as with European Union law

Conclusions: Co-existence and freedom of choice between the different agricultures is not effectively achieved by the existing individual solutions. Binding agricultural planning should therefore be introduced establishing e.g. genetically modified organism-free zones. Such measures are compatible with constitutional guarantees and with EU law.

Keywords: Co-existence, EU law, German law, GMO, Systemic character

\section{Background \\ EU law}

A European Commission Recommendation of 2003 sets out guidelines for the development of national strategies and best practices to ensure the co-existence of genetically modified organism (GMO) agriculture with conventional and organic farming [1]. The aim of the

\footnotetext{
* Correspondence: gwinter@uni-bremen.de; sramadan@uni-bremen.de University of Bremen, Research Centre for European Environmental Law, Universitaetsallee, GW I, 28359 Bremen, Germany
}

recommendation is to ensure that agricultural methods not using GMOs shall persist side by side with GMObased methods [2]. Co-existence shall ensure that farmers, industry, commerce and consumers have a free choice between conventional, organic and GMO crops [3]. This definition of co-existence shows that the basic idea of co-existence is the economic concern, not however environmental and health risks, as being emphasised by the traditional GMO law. The latter is dealt with by Directive 2001/18/EC [4] on the deliberate

\section{SpringerOpen ${ }^{\circ}$}

(C) 2011 Winter and Stoppe-Ramadan; licensee Springer. This is an Open Access article distributed under the terms of the Creative Commons Attribution License (http://creativecommons.org/licenses/by/2.0), which permits unrestricted use, distribution, and reproduction in any medium, provided the original work is properly cited. 
release of GMOs and Regulation 1829/03 [5] on genetically modified food and feed including seed (IT is controversial whether seed is comprised by the Regulation. However, it is common practice) [6]. Article 4 of the Directive states that the granting of an authorisation for the deliberate release of a GMO shall only be given, if a comprehensive risk assessment shows that there are no risks to the environment or health, or that the existing risks can be managed by appropriate measures, within the framework of risk management [7]. The same is done by Art. 4 of Regulation 1829/03. Separated from this risk-based approach, co-existence (even though it should implicitly serve to minimise environmental or health risks, too) aims at the protection of real assets: the possibility to sell products as GMO free.

\section{Proposal for amending the relevant EU law}

In July 2010, the Commission released a new Recommendation [8] on guidelines for the development of national co-existence measures to avoid the unintended presence of GMOs in conventional and organic crops, replacing the above mentioned Recommendation 2003/ $556 /$ EC of 23rd July 2003. It emphasizes inter alia the importance of making a clear distinction between health and environmental risks and promulgates the legitimacy of agricultural planning (including GMO-free regions). Moreover, the Commission proposed an amendment [9] to Directive 2001/18/EC recommending the inclusion of a new Article 26b to the Directive. According to this article, the decision whether GMOs may be cultivated or not is left to the member states (restricted however only to such reasons being not already taken into account in the risk analysis). As to the amendment of Directive 2001/18/EC, the European Parliament and the Council have not yet decided. Nevertheless, the mere proposal allows conclusions with regard to the future development of national co-existence regulations.

\section{German law}

Both aspects, risk assessment and co-existence, are implemented in the German Genetic Engineering Act (GenTG) [10]. Section 1 GenTG defines the aim of the law as to prevent risks to environment and health (Section 1 No. 1) and to ensure co-existence (Section 1 No. 2). However, the measures provided for these aims do not draw a clear line between the two concerns. For instance, the public register of sites of GMO agriculture required by Section 16a GenTG is designed to serve the double purpose of monitoring any possible risks to the environment and human health as well as ensuring coexistence. In the same vein the rules on good practice [11] define distance requirements between GMO and non-GMO crops to prevent on the one hand the contamination of neighbouring fields (thus protecting economic concerns of the non-GMO farmer) and on the other hand the presence of transgens in wildflowers (thus preventing environmental risks, c.f. Section 16b (3) No. 2 GenTG).

This intermixture of aims is reasonable because it helps to simplify administrative control. However, what is commanded by the two aims should be distinguished in the first place in order to finally find the optimal measure for both. For instance, economic reasons might call for much greater distance requirements than purely ecological ones because the simple presence of GMOs in a pollinated plant can entail an economic loss but not yet an ecological risk.

We concentrate on co-existence measures aiming at the economic aspect. Our question is if farmers effectively have the freedom of choice between conventional, organic and GMO crop production, and if not, what can be done about it.

\section{Results}

Measures of co-existence as laid down by German law (Sections 16a and 36a Act GenTG) and good practice rules (c.f. [11]) include the register on GMO release (Section 16a GenTG), duties of GMO farmers to inform neighbours of planned GMO release (Cf. Sections 16b (5), 18 (2) and 21 GenTG - duty to inform the authorities and participation of the public; Section 35 GenTG duty to inform the injured party, as well as Section 3 GenTPfEV(Regulation on the Production of Genetically Modified Crops) - duty to inform the neighbour prior to the planting of GMO), distance rules for planting like GMO and non-GMO crops (Annex to GenTPfEV, specific rules for plants), and liability for the contamination of neighbouring crops (Section 36a GenTG). All of these measures aim at solving conflicts between the individual landowners. In the nationwide register on GMO releases, information is displayed about the GMO (its name and characteristics), the property on which it will be released, the period in which it shall be cultivated and if applicable the name of the person farming the plot of land. The GMO farmer has to register the required information prior to cultivation (Section 16a (2) and (3) GenTG). The register is open to the public as far as the characteristics and the plot of land on which the GMO will be cultivated are concerned (Section 16a (1) sentence 3, in conjunction with (4) GenTG). Additional prior information duties rest upon the GMO farmer as he is obliged to inform his neighbour about the cultivation of GMOs at least 3 months prior to the cultivation (Section 3 (1) GenTPflEV). In case the GMO farmer does not get any response from the neighbour within 1 month after receipt, he can assume that the neighbour does not cultivate plants of the same kind as the GMO or able to cross out with it 
(Section 3 (2) GenTPflEV). If such plants are cultivated on neighbouring fields, the GMO farmer is obliged to meet the minimum distance requirements set out in the annex to the GenTPflEV (Section 4 GenTPflEV). Until now, only distance rules for GMO maize have been laid down. One hundred and fifty meters are required for the distance between GMO and conventional maize and $300 \mathrm{~m}$ for GMO and organic maize. In case the landowner complies with these regulations and the crops of the neighbour are nevertheless contaminated, although the crop was be labelled as GMO based or cannot be labelled as GMO free, the GMO farmer is liable for the damage arising out of this contamination (Section 906 Civil Law Code (Bürgerliches Gesetzbuch - BGB) together with Section 36a GenTG). The damage is calculated according to the impairment of saleability of the product as GMO free. In case the landowner complies with these regulations but the crops of the neighbour are nevertheless contaminated, the GMO farmer is liable for the damage arising out of the contamination, i.e. damage which the neighbour has to face because he must label his crops as GMO based or cannot label them GMO free.

The said legal measures strive for solving the conflict between agricultures on the local and individual level. The neighbouring farmers are expected to be able to come to an agreement. However, such individual conflict solutions are bound to fail for social and ecological reasons:

1. The information and coordination duties might be disrespected in the actual farming practice, because GMO farmers find them too burdensome, or the conventional farmers do not know or defend their rights, or, more fundamentally, because on the village level social rules and power structures prevail over legal rights and duties (in Spain, for instance, it was reported that many organic farmers "voluntarily" gave up because they did not see a chance to persist in a local culture and practice of GMO cultivation) [12].

2. The existing liability rules are limited to neighbours. This excludes farmers operating on distant plots as well as non-agricultural actors such as beekeepers [13].

3. The rules on minimum distances have the effect that in regions with small agricultural plots much land must be reserved - and wasted - for puffer functions.

An alternative approach should take into account that GMO agriculture is not a problem between single farmers but rather a conflict between entire statures of agriculture. This systemic character of the problem necessitates systemic measures. One measure could be landscape planning, another one the strengthening of multilateral voluntary agreements between landowners of a region.

\section{Landscape planning}

Taking Germany as a case landscape planning is aimed at (1) describing the present state and uses of natural areas and landscapes, (2) defining objectives of nature protection and landscape preservation, (3) evaluate the factual situation and (4) elaborate measures in view of the defined objectives (Section 9 (3) Federal Nature Protection Act (Bundesnaturschutzgesetz - BNatSchG)). According to the law, measures shall protect nature and landscape against damage (Section 9 (3) No. 4 (a) BNatSchG), but they can also be employed to preserve and develop the diversity, originality (Eigenart) and amenity of nature and landscape (Section 9 (3) No. 4 (f) BNatSchG).

The authors submit that the determination of areas where no GMOs shall be introduced can be one measure of this latter kind (concurring with this opinion, see [14]). For instance, the landscape plans could promulgate GMO-free regions, regions for organic production, regions recommended for GMO cultivation, etc.

Such use of landscape planning would be compatible with the already cited Commission Communication where it is said that "measures of a regional dimension could be considered. Such measures should apply only to specific crops whose cultivation would be incompatible with co-existence, and their geographical scale should be as limited as possible."[15]

When considering landscape planning as a tool of coexistence, it must however be noted that according to most German Länder laws landscape, plans are only binding in the internal administrative sphere. They do not create rights and duties of citizens. Nevertheless, even as a non-binding document, they can provide guidance for farmers.

\section{Voluntary multilateral agreements}

Voluntary multilateral agreements between the landowners are another method to arrange co-existence. They are mainly used to build up GMO-free regions. The attached map shows the present distribution of GMO-free regions in Germany (Figure 1; http://www. gmo-free-regions.org/gmo-free-regions/germany.html)

Of course, they can also be used for regions recommended for GMO production or regions for organic production.

Even though such agreements are binding for the parties, they do normally not encompass any sanctions in cases where a party does not comply with the agreement. Moreover, they are not binding for the successors 


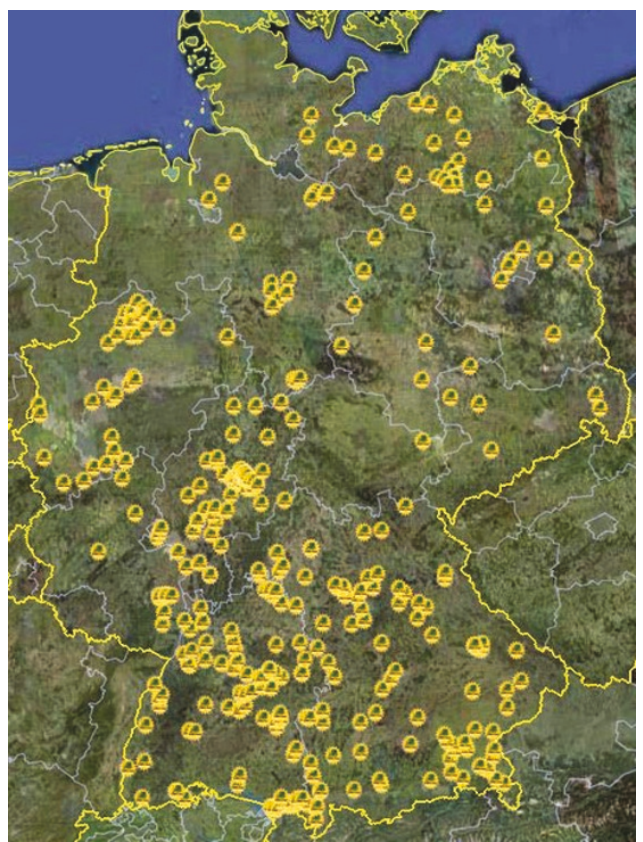

Figure 1 Map of GMO-free regions Germany 2010.

in landownership because the agreements usually are not secured by a servitude on the real estate.

As outlined, neither landscape planning nor voluntary agreements result in binding law. More effective solutions can be found in binding agricultural planning. In terms of legislative technique, three options are possible. Either the BNatSchG could be amended to open up landscape planning for agricultural planning and make it binding in that respect, or agricultural planning concerning GMOs could be included into the GenTG, or a separate law on agricultural planning could be designed. Besides ensuring co-existence, such planning could at the same time enhance environmental risk reduction. In the German case, it could be based on the competence for nature and landscape protection (Art. 74 No. 29 Grundgesetz) as well as the competence for support for agricultural production (Art. 74 No. 17 Grundgesetz).

\section{Discussion}

\section{Compatibility of the co-existence measures with constitutional guarantees}

Any measure trying to solve the conflict between GMO and non-GMO farmers, may it address the individual or the systemic conflict, raises questions of its compatibility with constitutional guarantees, and especially the protection of private property. The property guarantee could be affected:

1. because the GMO farmer must register his crop, keep the prescribed distances to non-GMO fields, compensate damages and - if introduced - obey the agricultural planning;

2 . because the non-GMO farmer must tolerate a certain amount of contamination by GMO pollen, bears the burden of proof with regard to economical damages through a GMO farmer and is compensated only under rather restrictive conditions (See Section 36a GenTG) ${ }^{\mathrm{a}}$

The following analysis concentrates on case 1 (GMO farmer) and only takes into account German constitutional law. A recent judgement of the German Federal Constitutional Court supports our views [16].

Property, as guaranteed by Art. 14 Grundgesetz (GG), means the right of use and disposal of all assets belonging to an individual. Hence, it includes the free choice of seeds for cultivation by a farmer. Restricting this choice by notification and compensation duties is an intervention into his property right. However, any property is subject to the moulding and limitations defined by the legislator in view of the public interest (Art. 14 (1) GG). While there is broad discretion of the legislator to define the extension of the protected property and to limit its uses, the legislator must respect the core functions of private property (called institutional guarantee in German constitutional doctrine) such as securing private goods for an individual's self-fulfilment. In addition, the intervention into private property must obey the proportionality principle. An expropriation is only possible if necessary to satisfy an imperative public interest and adequate compensation is provided.

Subsuming the case of the GMO farmer under these rules, it is clear from the outset that the restrictions do not amount to an expropriation. Moreover, the core functions of the property guarantee are not affected because the farmer's business, not his personal development, is at stake.

The public interest justifying the intervention can be found in the very objective of co-existence of different kinds of agriculture. In particular, there is a public interest to allow non-GMO farmers to carry on and provide non-GMO food for those consumers who have a preference for non-GMO food. This public interest is even backed by constitutional rights of property of third parties. This includes the property right of the non-GMO farmer, i.e. to be protected against contamination and to freely use his property for non-GMO cultivation. ${ }^{\mathrm{b}}$ It may also include the personal freedom of consumers to have a free choice of goods between GMO and nonGMO products.

Proportionality further demands (amongst others) to check that no less restrictive measures could have been used to satisfy the public interest. Voluntary cooperation between farmers may be considered as an option. 
However, they would not solve situations where no consensus can be obtained. Therefore binding measures are unavoidable. As to whether individual or systemic measures should prevail the shifting of conflict resolution to the local and individual level appears to be less restrictive than binding agricultural planning. But, as shown above, individual measures do not effectively ensure coexistence. For instance, given the fact that pollen is transported over long distances, land corridors around GMO fields may fail to separate productions over the long term. Therefore, also binding measures would pass the test of proportionality.

\section{Compatibility of measures with EU law}

It must further be analysed, whether binding agricultural planning defining regions where GMOs can be cultivated and where not would infringe EU law. According to Art. 22 Directive 2001/18/EC "Member States may not prohibit, restrict or impede the placing on the market of GMOs, as or in products, which comply with the requirements of this Directive." This provision is breached if the designation of GMO-free regions must be considered as an impediment of the placing on the market of the genetically modified seed. The answer is in the negative because the designation would be concerned with the use of the GMO. The GMO could still be freely sold and purchased on the market. This could be different if the whole territory of a member state would be closed for GMO application. Then, the placing on the market would be impeded de facto because of low demand for the seed. ${ }^{\mathrm{c}}$ However, GMO-free regions are not supposed to cover the entire territory of a member state.

Assumed that the designation of GMO-free regions would nevertheless be considered as an impediment to the placing on the market of the seed, a member state could make use of its right under Art. 114 (5) Treaty on the Functioning of the European Union (TFEU). This provision allows member states to introduce legislation which goes further than the EU legal act in protecting human health and the environment, but only if new scientific findings on risks and a new problem specific to the member state advise accordingly. The European Courts ruled on this question in the case of GMOs in the Land Upper Austria (Oberösterreich) [17]. The Land had drafted a regulation prohibiting any cultivation of GMO plants in its entire territory. The Republic of Austria asked the commission for approval according to Art. 95 (5) TEU (now Art. 114 (5) TFEU) arguing that the regulation was destined to protect small-scale farming and the unique nature in Oberösterreich. The commission decided that the prerequisites - new scientific findings on risks and a specific problem of the member state - were not given. The Republic of Austria appealed against this decision at the European Court of First Instance.
The Court subscribed to the view of the commission mainly based on the grounds that small-sized farms were not a specific problem of Austria, and that the concerned ecosystems were not unique. Therefore, it did not regard it necessary to decide whether the mentioned scientific findings were new. Based on these grounds, the court decided that the legal provision of the Republic of Austria infringed EU law. Upon appeal, the ECJ upheld this decision.

In relation to binding agrarian planning as here proposed, the question arises if establishing GMO-free zones would - according to this jurisprudence - be compatible with Art. 114 TFEU. We submit that this is the case [18]. We are of the opinion that the European Courts held only those measures inadmissible which concerned the whole territory of a member state region. By contrast, measures of a local character based on reasonable grounds (like co-existence) are not even captured by the scope of application of Art. 114 (5) TFEU. They do not go further than EU law because the authorization for the bringing on the market of a GMO does not preclude the regulation of uses at the spot. Likewise, for instance, the authorization of the placing on the market of a pesticide does not exclude that a member state prohibits the usage of pesticides in water or nature protection areas. The authorization under Directive 2001/18/EC does not mean that the GMO has to be used everywhere. Of course, such measures may not be so extensive that this amounts to a de facto moratorium of the placing on the market of GMOs (see Endnote ${ }^{\mathrm{c}}$ ).

\section{Conclusions}

Co-existence and freedom of choice between the different agricultures is not effectively achieved by the existing individual solutions to the conflict. Agricultural planning should therefore be introduced establishing, e. g. GMO-free zones. As outlined, neither landscape planning nor voluntary agreements result in binding law. More effective solutions can be found in binding agricultural planning. Such measures are compatible with constitutional guarantees as well as with EU law.

\section{Methods}

The pertinent EU and German law of the EU and of Germany is analysed using the common methodology of law interpretation. Effects of the law are predicted and explained by educated guess. On that basis, reform proposals are developed and tested as to possible conflicts with constitutional guarantees following the methodology of application of basic rights.

\section{Endnotes}

${ }^{\mathrm{a}}$ An example for the limited protection by Section $36 \mathrm{a}$ GenTG are beekeepers. They have to face the problem 
of their honey getting contaminated with GMO pollen. In the case of Brandenburg for example, pollen of the maize MON 810 was found in the honey. The beekeeper applied for appropriate measures of the competent administrative body to avoid contact of his bees with the said maize pollen. The judge agreed in the fact that beekeepers come into a hopeless situation if the deliberate release of GMOs is expanding; however, it is for the legislator to find a solution to this problem. Until now, beekeepers are not considered by the liability rules of the GenTG. Yet, a duty to encompass them can be concluded by looking at the Commission's recommendation that all member states should analyse their liability rules on whether they consider all affected parties.

${ }^{\mathrm{b}}$ This reasoning was recently sustained by the German Federal Constitutional Court (Bundesverfassungsgericht) in its judgement of 27 November 2010, Case 1 BvF 2/ 05, n.y.r..

${ }^{\mathrm{c}}$ This construction has recently been developed by the European Court of Justice (ECJ), see judgement of 10 February 2009, case C-110/05 (Motorcycles), E.C.R. 2009, I-519, No. 56 f. and judgement of 4 June 2009, case C-142/05 (Mickelsson), E.C.R., No. 24.

\section{Authors' contributions}

GW and SSR carried out the legal analysis on the said question. All authors read and approved the final manuscript.

\section{Competing interests}

The authors declare that they have no competing interests.

Received: 22 February 2011 Accepted: 29 July 2011

Published: 29 July 2011

\section{References}

1. . Commission Recommendation of 23 July 2003, 2003/556/EG, O.J. L 189/36 of 29.07.2003.

2. Commission Recommendation 2003/556/EG (Fn.1), recital 1 and 3 .

3. Commission Recommendation 2003/556/EG (Fn.1), recital 3.

4. Directive 2001/18/EC of the European Parliament and of the Council of 12 March 2001 on the deliberate release into the environment of genetically modified organisms and repealing Council Directive 90/220/ EEC. , O. J. L 106/1 of 17 April 2001

5. Regulation (EC) No. 1829/2003 of the European Parliament and the Council of 22 September 2003 on genetically modified food and feed. Official Journal L 268/1 of 18 October 2003.

6. Winter G: Naturschutz bei der Ausbringung von gentechnisch veränderten Organismen, Teil 1. Natur und Recht 2007, 29:571-587.

7. Art. 4 in conjunction with Art. 2 and Annex II A. of Directive 2001/18/EC.

8. Commission Recommendation of 13 July 2010, 2010/C 200/01, O. J. C 200/1 of 22.07.2010.

9. Proposal for a Regulation of the European Parliament and of the Council amending Directive 2001/18/EC as regards the possibility for the Member States to restrict or prohibit the cultivation of GMOs in their territory, Com (2010) 375 final.

10. German Genetic Engineering Act of 16 December 1993. BGB/ / 2066, latest amended version of 29 July 2009 BGBI. I, p. 2542.

11. German Regulation on production of genetically modified plants (Gentechnik-Pflanzenerzeugungsverordnung - GenTPfIEV) of 7 April 2008. BGB/ / 655 .
12. Binimelis R: Coexistence of plants and coexistence of farmers: is an individual choice possible? Journal of Agricultural and Environmental Ethics 2008, 21(5):437-458.

13. See on the serious restrictions of the rights of beekeepers Oberverwaltungsgericht Berlin-Brandenburg, Beschluss v. 27.06.2007, Az 11 S. 54.07.

14. Dederer H-G: Weiterentwicklung des Gentechnikrechts - GVO-freie Zonen und sozioökonomische Kriterien für die GVO-Zulassung. Berlin: LIT; 2010, 95.

15. , Commission Recommendation of 23 July 2003 on guidelines for the development of national strategies and best practices to ensure the coexistence of genetically modified crops with conventional and organic farming (notified under document number C(2003)2624, Introduction 2.1.5. 16. , BVerfG, 1 BvF 2/05 vom 24.11.2010.

17. , Court of First Instance, Judgment from 5th October 2005, T-366/03 and T235/07, and ECJ judgment from 13th September 2007, C-439/05.

18. Winter G: Naturschutz bei der Ausbringung von gentechnisch veränderten Organismen, Teil 2. Natur und Recht 2007, 635-641, (639).

doi:10.1186/2190-4715-23-28

Cite this article as: Winter and Stoppe-Ramadan: European Union and German law on co-existence: Individualisation of a systemic problem. Environmental Sciences Europe 2011 23:28.

\section{Submit your manuscript to a SpringerOpen ${ }^{\mathcal{O}}$ journal and benefit from:}

- Convenient online submission

- Rigorous peer review

- Immediate publication on acceptance

- Open access: articles freely available online

- High visibility within the field

Retaining the copyright to your article

Submit your next manuscript at $>$ springeropen.com 